\title{
WIDE-SCREEN TELEVISION AND HOME MOVIES
}

\author{
TOWARDS AN ARCHAEOLOGYOF TELEVISION \\ AND CINEMA CONVERGENCE BEFORE \\ D IG ITALISATION
}

\author{
Tom James Longley Steward \\ Independent Researcher \\ 4345 37th Street \\ San Diego, California \\ USA 92105 \\ tomsteward1@outlook.com
}

\begin{abstract}
In this article, Tom Steward uses past interrelations of television and cinema spectatorship, exhibition, production and aesthetics to historicize phenomenological digital-era discourses on, ontological definitions of, and cultural arguments about television and cinema convergence. He argues that television and cinema assisted in defining each other as late $20^{\text {th }}$ Century media and cultural forms, have a multi-directional industrial and artistic flow, and are often interdependent in reception and distribution. Television and cinema convergence demonstrates the need for historical breadth in media convergence theory and an understanding of medium-specificity that incorporates interactions with other media.
\end{abstract}

Keywords: television, cinema, convergence, history, spectatorship, exhibition, production, aesthetics

\section{Introduction}

Scholarship on the convergence of television and cinema has severely marginalised the historical dimensions of the relationship between the two media. Media scholars, including John Thornton Caldwell, ${ }^{1}$ have thought of cinema and television convergence as a by-product of recent shifts in media industries, technologies and consumption towards digitalisation and conglomeration. Philosophical arguments about the ontologies of cinema and television, such as those proposed by Noel Carroll, ${ }^{2}$ have effaced historical distinctions between cinema and television and re-interpreted their convergence as an essential characteristic of the moving image. Film Studies historiography has tended to portray convergence with television as a symptom of the artistic demise of cinema ${ }^{3}$ while some interdisciplinary historians have

1 John Thornton Caldwell, 'Welcome to the Viral Future of Cinema (Television)', Cinema Journal 45, 1 2005, pp. 90-97: http://www.tft.ucla.edu/wpcontent/uploads/2012/02/2005-Welcome-to-the-Viral-Future-of-Cinema-CINEMA-JOURNAL.pdf

2 Noel Carroll, Engaging the Moving Image, Yale University Press, 2003.

3 Todd Gitlin, 'Down The Tubes' in Mark Crispin Miller, eds, Seeing Through Movies, Pantheon Books, 1990, pp. 15-48; James Monaco, How to Read a Film: Movies, Media and Beyond, Oxford University Press, 1981. 
exploited convergence in order to advocate the cultural and artistic dominance of one medium over the other. ${ }^{4}$ As Christopher Anderson has shown, ${ }^{5}$ there is a body of revisionist historiography, which identifies a 'symbiotic relationship' between television and cinema spanning their overlapping histories. ${ }^{6}$ While this scholarship has gone a long way in highlighting the intertwined aesthetic, industrial and cultural histories of cinema and television, it has not necessarily lessened the value judgements cast on each medium and can occasionally lapse into an argument for ontological synonymy rather than sustained historical interaction.

This article argues that phenomenological digital-era discourses on television and cinema convergence must be historically contextualised in light of interrelations apparent from the inception of television. It contends that convergence should be explored in relation to how each medium has been appropriated historically rather than in the ontological abstract. I concur with the revisionist view of cinema and television convergence evident in recurring historical interrelations, but do not seek to make cultural and artistic arguments about the two media nor assumptions about their integration. I overview how specific practices of exhibition, form and industry in television and cinema have permeated each other and how they assisted in defining each other's late $20^{\text {th }}$ century identity as media and cultural forms. I look at television and cinema spectatorship technologies developed in relation to the other medium, how the film industry attempted to control television exhibition, and the impact of domestic consumption on cinema distribution. I address the agency of television in developing cinematic form from rolling content into single features and the use of film in television broadcasting. I consider pre-conglomerate industrial mergers in television and cinema and the inter-play of film and television artists in key historical periods.

My approach is historically and critically reflexive. I use a wide range of historical examples of film and television convergence across production and reception to convey the frequency with which they interrelated as well as the contingency of their relationship as media. I do not claim to present a comprehensive history of television (or indeed film) but rather touch on significant moments of overlap that suggest a longstanding and far-reaching engagement between the cultural and creative practices of the two media. Throughout the article, I analyse historiography and scholarship in the field. It is not my intention to simply rake over ground already covered by film and television historians but to use existing scholarship to discover a history of media convergence pre-dating digital paradigms, and to offer a nuanced and original perspective on those convergences through recourse to work in the area. While I have selected exhibition, form and industry as the areas in which film and television convergence have been most visible, these observations are applicable to other considerations, such as aesthetics and audiences. The article offers a starting point for understanding the convergence of film and television as rooted in history rather than in moving image ontology, digital media, or taste regimes.

\section{Exhibition}

Across their shared history, television and cinema have accommodated each other's spectatorial conventions and practices. In the mid-1950s, Hollywood studios institutionalised a number of spectator technologies developed from patents in early European cinema, including stereoscopic 3-D cinema and various anamorphic lens formats such as CinemaScope. As film historian Tino Balio argues, these were counter-strategies designed to "differentiate its product from television" in response to increasing competition for US leisure consumers from TV networks in the early 1950's, and were typically devices for "presenting pictures in a spectacular fashion" against the close quarters of the small screen. ${ }^{7}$ Competition with TV elicited a cinematic mode of spectatorship in complete contrast to television; colourful, wide and multi-dimensional compositions rather than black-and-white, square and flat transmissions. The connection is not merely dialectical. If, as Stephanie Marriott suggests, medium-specificity is a product of the "history of its contexts of

4 Martin McLoone, 'Boxed In?: The Aesthetics of Film and Television' in John Hill and Martin McLoone, eds, Big Picture, Small Screen: The Relations between Film and Television, University Of Luton Press, 1996, pp. 76-106; Stuart Klawans, 'Colorization: Rose-Tinted Spectacles' in Mark Crispin Miller, ed, Seeing Through Movies, Pantheon, 1990), p 150-185.

5 Christopher Anderson, Hollywood TV: The Studio System in the Fifties, University of Texas Press, 1994, p. 13.

6 Michelle Hilmes, Hollywood and Broadcasting: From Radio to Cable, University of Illinois Press, 1990; Tino Balio, ed, Hollywood in The Age of Television, Unwin Hyman, 1990; William Boddy, Fifties Television: The Industry and its Critics, University Of Illinois Press, 1993.

7 Tino Balio, ed, Hollywood in The Age of Television, Unwin Hyman, 1990, p. 24. 
appropriation" rather than ahistorical ontology, ${ }^{8}$ conceptualisations of cinema as a medium of scale, width and depth of image may partly derive from its economic interconnectedness with television. Interestingly, cinematic spectatorship counter-strategies were focused on the auditorium and stressed the live aspects of film viewing. Cinema competed with television by manufacturing its potential for liveness and simultaneous reception.

Todd Gitlin's damning account of TV's influence on cinema, ${ }^{9}$ however, argued that rather than stressing the distinction of cinema, spectatorship technologies used to combat television's economic threat took Hollywood studios down a road of novelty and spectacle from which it has never recovered. These so-called "gimmicks," Gitlin suggests, "settled into the niches that television lacks the technology or permission to occupy - those which exploit the size of the screen, the quality of the sound," and compelled filmmakers from the 1960s onwards to steer films towards the spectacular, the graphic and the superficial. ${ }^{10}$ Leaving aside the rhetoric of Gitlin's argument, he has captured quite effectively the notion that what television cannot do (at least at this point in history) comes to define what cinema is. In this sense, television compels cinema to come to terms with what Marriott calls "communicative affordances,"11 uses that some media are better-suited to than others, without becoming essential characteristics. Indeed, television has given cinema technological models for achieving spectatorial distinction from media posing an economic threat. The market dominance of home and mobile digital media has been met by industry-wide revival of 3-D in contemporary digital cinema and the resurgence of big-screen differentiation in the IMAX cinema.

Caldwell cites the advent of the DVD as evidence that cinema has become a medium of "domestic consumption" (and hence an adjunct of television ${ }^{12}$ but the notion of cinema as conducive to TV screens and the domestic milieu has a much longer history. As historian John Belton has outlined, cinematographers from the 1960s onwards reduced their wide-screen compositions to keep action and visual elements within a "frame-within-a-frame.... in order to accommodate itself to a new subsidiary market-the sale of motion pictures to television." ${ }^{13}$ Bruce R. Austin writes about compacted film aesthetics in the era of the VCR, continuing this narrative of TV shrinking the cinema image in the context of "the importance of home video... as an ancillary market for movie revenues." ${ }^{14}$ This historiography is clouded by lament for "the role that television played in its [cinema's] decline"15 consistent with James Monaco's "end of cinema" narrative, ${ }^{16}$ which Anderson associates with the majority of scholarship on this topic. ${ }^{17}$ The scholarly synonymy between reformatting cinema for TV screens and the artistic and visual compromise of cinema is best demonstrated by Stuart Klawans' work, ${ }^{18}$ which contends that the cinematic specificity and tactile nature of film images are damaged through television airings of movies.

Martin McLoone has perceptively described this position as the belief that "television 'boxes-in' the cinematic imagination of the filmmaker and the cinematic experience of the audience."19 Unfortunately McLoone's own position continues to "favour cinema ahead of television," arguing that "film opened out the televisual experience and...rescued television drama from its theatrical influences." ${ }^{20}$ I am not concerned with aesthetic judgements about what either

8 Stephanie Marriott, Live Television: Time, Space and the Broadcast Event, Sage, 2007, p. 13.

9 Todd Gitlin, 'Down The Tubes' in Mark Crispin Miller, ed, Seeing Through Movies, Pantheon Books, 1990, pp. $15-48$.

10 lbid, p. 43.

11 Stephanie Marriott, Live Television: Time, Space and the Broadcast Event, Sage, 2007, p. 13.

12 John Thornton Caldwell, 'Welcome to the Viral Future of Cinema (Television)', Cinema Journal 45, 1 2005, p. 92: http://www.tft.ucla.edu/wpcontent/uploads/2012/02/2005-Welcome-to-the-Viral-Future-of-Cinema-CINEMA-JOURNAL.pdf

13 John Belton, 'Glorious Technicolor, Breathtaking CinemaScope, and Stereophonic Sound in Tino Balio, ed, Hollywood in The Age of Television, Unwin Hyman, 1990, p. 206.

14 Bruce A. Austin, 'Home Video: The Second Run “Theater” of the 1990s' in Tino Balio, ed, Hollywood in The Age of Television, Unwin Hyman, 1990, p. 319.

15 John Belton, 'Glorious Technicolor, Breathtaking CinemaScope, and Stereophonic Sound in Tino Balio, ed, Hollywood in The Age of Television, Unwin Hyman, 1990, p. 206.

16 James Monaco, How to Read a Film: Movies, Media and Beyond, Oxford University Press, 1981, p. 302.

17 Christopher Anderson, Hollywood TV: The Studio System in the Fifties, University of Texas Press, 1994, p. 13.

18 Stuart Klawans, 'Colorization: Rose-Tinted Spectacles' in Mark Crispin Miller, ed, Seeing Through Movies (New York: Pantheon, 1990$),$ p. $150-185$. 19 Martin McLoone, 'Boxed In?: The Aesthetics of Film and Television' in John Hill and Martin McLoone, eds, Big Picture, Small Screen: The Relations between Film and Television, University Of Luton Press, 1996, p. 81.

20 Ibid, p. 86. 
medium did for the cultural legitimacy of the other but rather how attempts to maintain the artistic value of each medium in the convergence process forged new forms of presentation. Belton suggests that cinema's reduction of cinematic images was "to protect themselves from the ravages of panning and scanning" 21 and hence a means of preserving the integrity of cinema against an image more characteristic of television. Monaco's notion of the post-1980 dissolution of "a distinct separation between what we call film and what we call video, or television"22 belies the fact that sale to TV redefined cinema spectatorship as applicable across screen contexts, a concept central to understanding media in the age of digital convergence. Noel Carroll's work on the moving image ${ }^{23}$ is particularly valuable for demonstrating that there is a longstanding flexibility of spectatorship across television and film straddling public and private space, live and recorded material, and high and low-quality images that pre-figure the normalising of multi-platform media by digital convergence. The fluid means of reception does not imply a loss of medium-specificity. Lucy Mazdon's account of French pay-television channel Canal Plus's commitment to original formats and image quality in airings of films ${ }^{24}$ suggests that televisation can withstand threats to the autonomy of cinema.

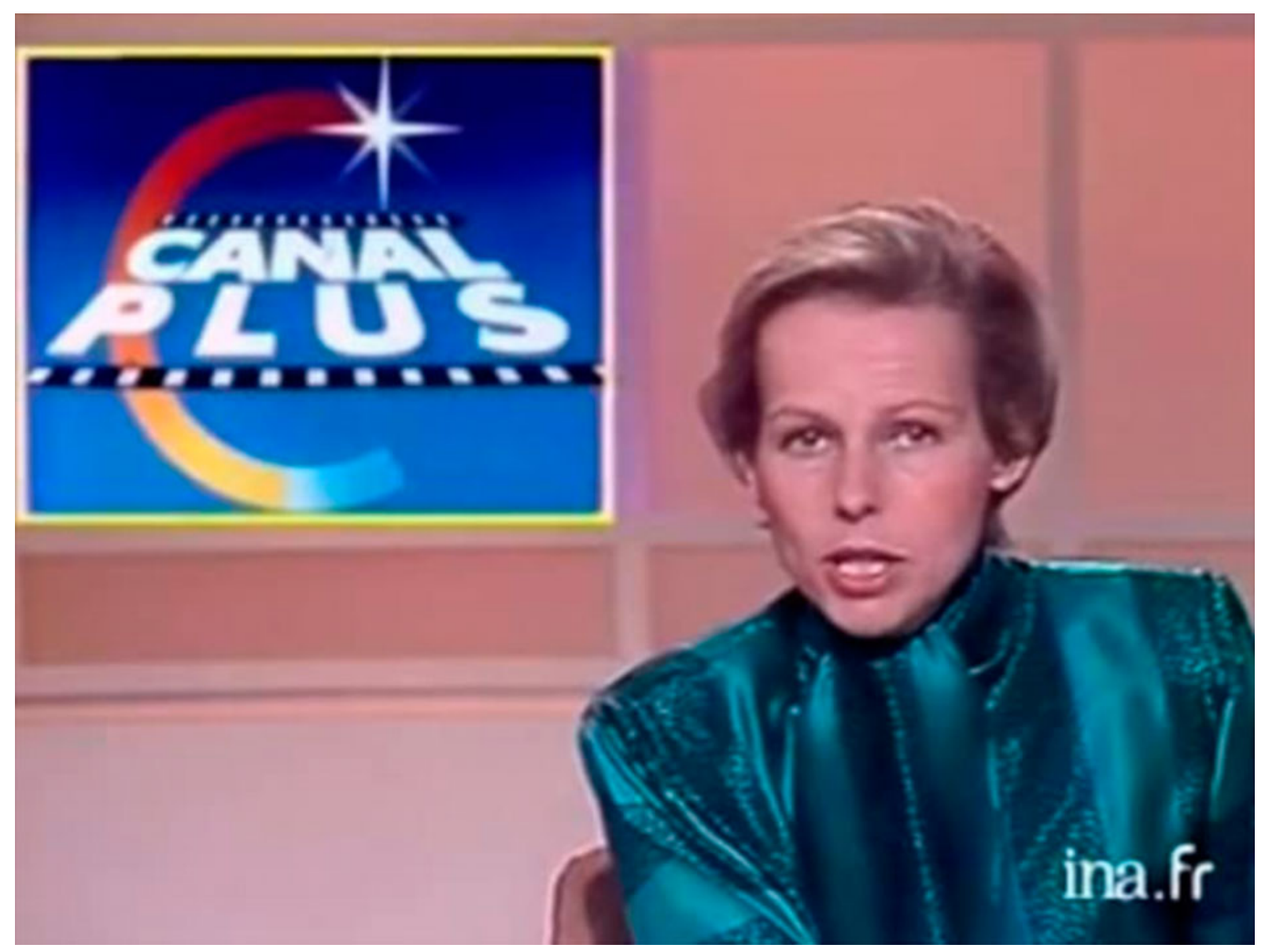

Video 1. The opening of Canal Plus. Click here to watch it

21 John Belton, 'Glorious Technicolor, Breathtaking CinemaScope, and Stereophonic Sound in Tino Balio, ed, Hollywood in The Age of Television, Unwin Hyman, 1990, p. 206.

22 James Monaco, How to Read a Film: Movies, Media and Beyond, Oxford University Press, 1981, 302.

23 Noel Carroll, Engaging the Moving Image, Yale University Press, 2003, p. 278.

24 Lucy Mazdon, 'Cinema and Television: From Emnity to Interdependence' in Michael Scriven and Monia Lecomte, eds, Television Broadcasting in Contemporary France and Britain, Berghahn Books, 1999, p. 72. 
Cinematic spectatorship practices have been circulating in television from the outset. Movie studios were determined to control television exhibition, demonstrated by investment in and development of television technology and facilities in the 1940s as TV broadcasting got underway to distribute television transmissions for fees and subscriptions through a pay-per-view system (Pay Television) and in cinemas (Theater Television). As Timothy R. White's account of Paramount Studios' intervention in the development of Theater and Pay Television suggests, ${ }^{25}$ the cinema industry wanted to appropriate television towards their existing exhibition models. Seeking to transmit a programme of live (rather than recorded) events by streaming them into movie theatres demonstrated that cinema wanted to capitalise on the potential of TV broadcasts to show images simultaneous to the events they were witnessing while establishing it as a theatrical and admission-based medium. Accepting that television would emerge as a home broadcast communication media as with radio and telecommunications; the film industry envisioned that the medium could be kept within the fee-based economics of cinema and its audiences. Although these forms of Pay and Theater Television never came to fruition (for regulatory rather than ontological reasons) the proposed convergence would influence later incarnations of television and cinema.

The television industry reappropriated the Pay Television model in the eras of cable, satellite and digital television with service, channel and content alternatives to free-to-air broadcast television available either through subscriptions or one-time fees. Tellingly, many of these channels and programmes prominently feature the live event content that cinemas were to charge admission to exhibit; sports, concerts, theatre. The model is also conventionally used when television content approaches the stand-alone qualities of feature cinema, such as televised films and major sporting events. Theater Television featured in the early 1950's where popular sporting events were transmitted live in cinemas, as in European cities. It has a continuing cultural relevance in television broadcasts in public and commercial meeting places. Public television is generally centred around live-transmitted events, such as sports, and in parts of the developing world it can even surrogate for domestic reception. ${ }^{26}$ Public television reconciles the simultaneous copresence of television viewing with the physical proximity of collective cinema auditorium spectatorship. Theater Television has been revived by the recent phenomenon of Event Cinema, where live cultural events (plays, operas, ballets) are shown by or transmitted into cinemas, a practice particularly popular in the UK and Sweden in the past few years.

\section{For m}

John Ellis's work on distinguishing television from cinema has pointed to the interdependence of television and late $20^{\text {th }}$ century cinema in terms of form. ${ }^{27}$ Ellis found that as television grew as a mass-medium mid-century its schedule of mixed programming negated the demand for cinema to exhibit a variety of segments (cartoons, newsreels, multiple features) in one programme, allowing it to 'unbundle' and become a medium distinguished by single features. ${ }^{28}$ Following Ellis' logic, we can also see that television's ongoing broadcast flow supplanted the rolling cycle of film programming that played in cinemas until the mid- $20^{\text {th }}$ century, replaced by feature films in separated timeslots. In particular, newsreels such as British Pathe News and the Italian La Settimana Incom which played in cinemas throughout the first half of the $20^{\text {th }}$ century featured an assortment of news, current affairs and topical interest stories and were often run in cinemas continuously throughout the day. The significance of this is first that television and cinema were at a given point in history exhibited in almost identical ways, and that their formal divergence was a matter of historical contingency not medium-specificity, since both media could be exhibited in this way but were not always required to at particular times. Secondly, it is evident that the conceptualisation of cinema as a medium of bounded, discrete texts of (somewhat) indeterminate length we are accustomed to derive from the release from programming offered by television. In a cultural sense, television permits cinema to adopt a presentational form consonant with art.

25 Timothy R. White, 'Hollywood's Attempt at Appropriating Television: The Case of Paramount Pictures' in Tino Balio, ed, Hollywood in The Age of Television, Unwin Hyman, 1990, p. 145-162.

26 John Ellis, Visible Fictions: Television: Cinema: Video, Routledge, 2001, p. 11-12.

27 John Ellis, 'What Is Television?' Keynote Address, Nordic Media Festival, 7 May 2010.

28 Ibid. 


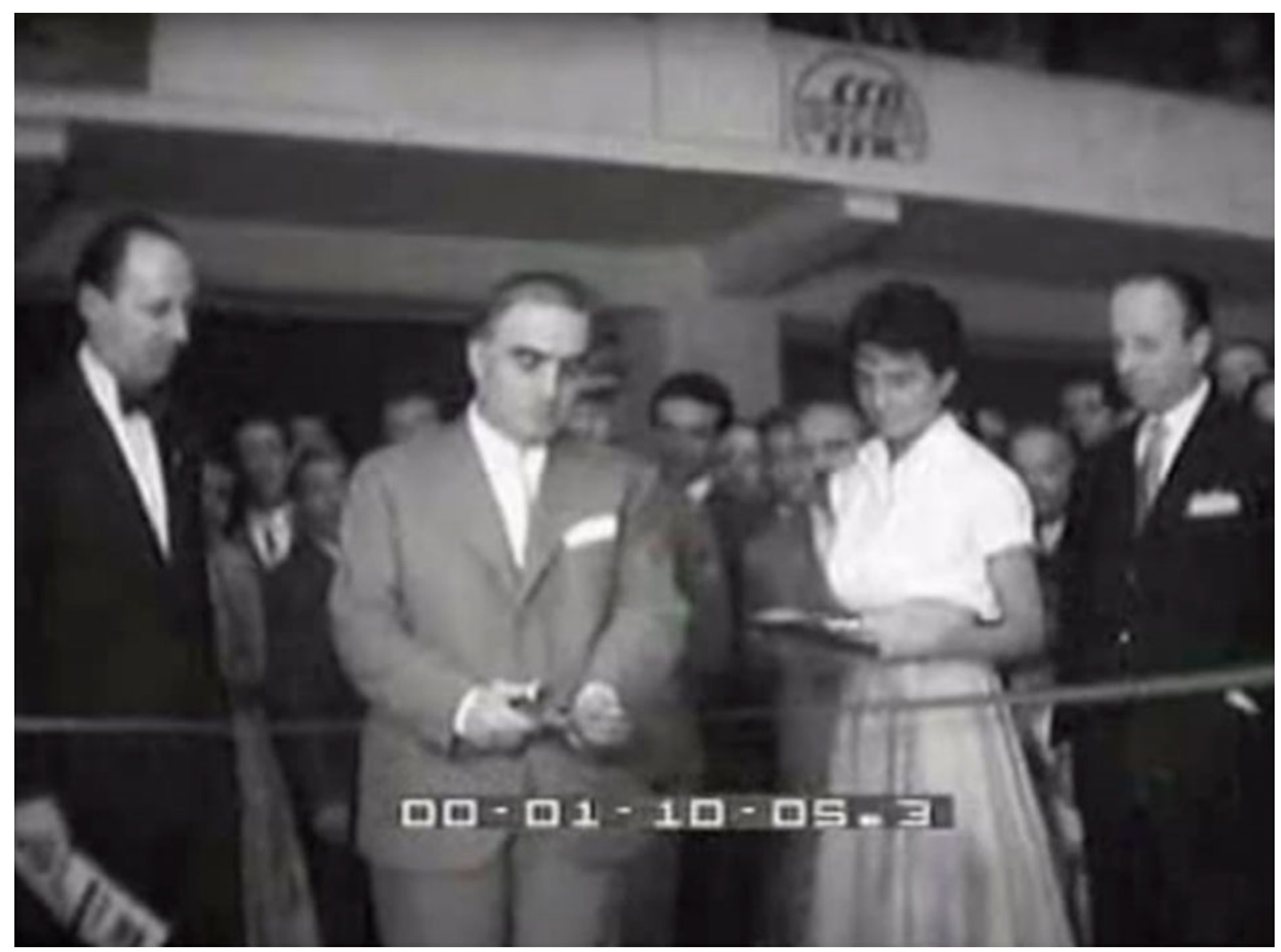

Video 2. 20th exhibition on Radio and television. Click here to watch it

The potential in television for seriality, that is the development of storylines and characters over time, has been thought of as one of the most distinguishing characteristics of the medium, and its route to cultural legitimacy. ${ }^{29}$ Serial form is identified as medium-specific partly because it harnesses the ongoing broadcast and reception of television as well as the capacity of broadcasting to construct a sense of our daily lives. Crucially, however, serial form distinguishes television from cinema. As there are issues of cultural value at stake, the genealogy of TV seriality is more often traced back to the $19^{\text {th }}$ century serial novel than its more apparent though less culturally valid ancestor, the film serial. Conversely, the form is seen within a broadcasting lineage through radio and television soap opera. Nonetheless, television's use of serial form is indebted to prominent film serials from the teens to the 1950s, such as Louis Feuillade's Fantomas (1913-1914) and Les Vampires (1915). We can see television's adoption of the film serial technique of melodramatic 'cliffhangers' between instalments and production within well-defined popular genres. The position of film serials as segments within an early-century mixed cinema programme and their subsequent television import and adaptation testifies further to this convergence. This is yet another example of how the desire for cultural legitimacy in one medium triggers convergence with another.

Television scholars such as Jane Feuer and Mimi White ${ }^{30}$ have written about the "ideology of liveness myth" in television history and criticism. Historical contexts of live television broadcasting are obscured as potential in television

29 Robert J. Thompson, Television's Second Golden Age: From Hill Street Blues to ER, Syracuse University Press, 1997; Glen Creeber, Serial Television: Big Drama on the Small Screen, BFI, 2005.

30 Jane Feuer, 'The Concept of Live Television: Ontology as Ideology' in E. Ann Kaplan, ed., Regarding Television, The American Film Institute, 1983, p. 12-23; Mimi White, 'The Attractions of Television: Reconsidering Liveness', in Nick Couldry and Anna McCarthy, eds, Mediaspace: Place, Scale and Culture in a Media Age, Routledge, 2004, p. 75-91. 
for simultaneous transmission and reception becomes ontological assertion of television as "the live, the immediate, the direct, the spontaneous, the real. ${ }^{31}$ Feuer and White accept television "can be live"32 but question whether television practice "exploits television's potential for 'unmediated' transmission." ${ }^{33}$ Feuer and other critics including Noel Carroll ${ }^{34}$ have made the argument that television becomes "less and less of a 'live' medium" as it goes on and more distinguished by pre-recorded and filmed content (with Feuer believing this is inversely proportionate to TV liveness myths) ${ }^{35}$ but arguably early television also relied heavily on recording and film. Early live television such as anthology drama was interspersed with pre-recorded film inserts, particularly for exteriors or specific locations, which made 'live' television broadcasts, such as BBC Television's adaptation of Nineteen-Eighty-Four (1954), a hybrid of transmission and recording, television and cinema. McLoone demonstrates that as early as the late 1950s live dramas were phased out in favour of filmed programming which become "elements in a varied schedule" not "the medium's defining characteristic." ${ }^{36}$

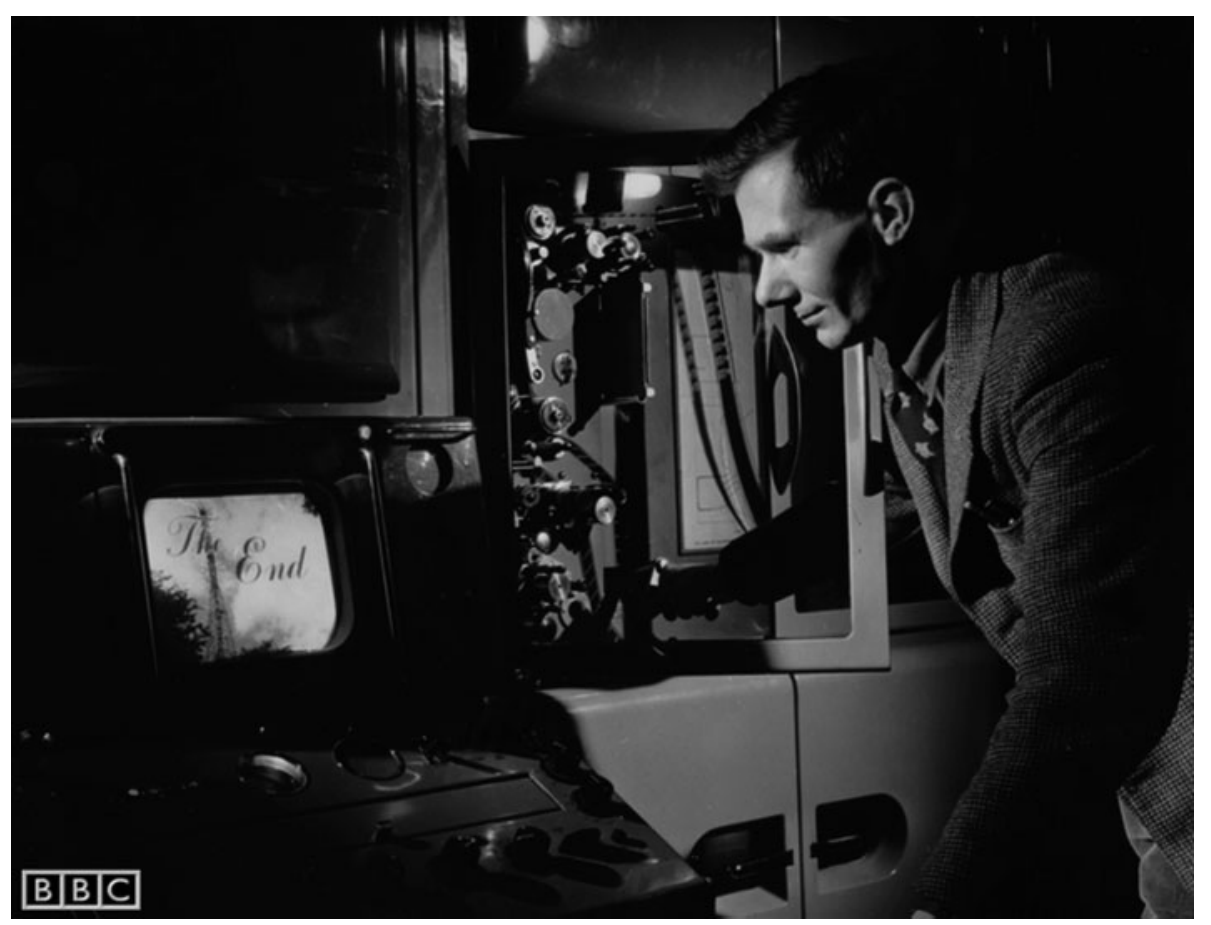

Video 3. A telecine machine at Alexandra Palace. Click here to watch it

Scholars have attempted to reconcile contradictions between the increasingly marginal status of live transmission within television and the continuing relevance of liveness to the medium. Charles Barr ${ }^{37}$ does this by drawing distinctions

31 Jane Feuer, 'The Concept of Live Television: Ontology as Ideology' in E. Ann Kaplan, ed, Regarding Television, The American Film Institute, 1983, p. 15.

32 Mimi White, 'The Attractions of Television: Reconsidering Liveness', in Nick Couldry and Anna McCarthy, eds, Mediaspace: Place, Scale and Culture in a Media Age, Routledge, 2004, p. 81.

33 Jane Feuer, 'The Concept of Live Television: Ontology as Ideology' in E. Ann Kaplan, ed, Regarding Television, The American Film Institute, 1983, p. 13.

34 Noel Carroll, Engaging the Moving Image, Yale University Press, 2003, p. 276.

35 Jane Feuer, 'The Concept of Live Television: Ontology as Ideology' in E. Ann Kaplan, ed, Regarding Television, The American Film Institute, 1983, p. 15.

36 Martin McLoone, 'Boxed In?: The Aesthetics of Film and Television' in John Hill and Martin McLoone, eds, Big Picture, Small Screen: The Relations between Film and Television, University Of Luton Press, 1996, p. 86.

37 Charles Barr, "They Think it's all Over": The Dramatic Legacy of Live Television' in John Hill and Martin McLoone, eds, Big Picture, Small Screen: The Relations between Film and Television, University Of Luton Press, 1996, p. 47-75. 
between time in television and cinema. He argues that what distinguishes television from cinema ontologically is its ability to transmit live images: "Television was...developed as a device for capturing and showing images simultaneously, or virtually so: images of the present, not of the (distant or recent) past...cinema cannot, by definition, diversify into present-tense or live images." ${ }^{38}$ When recording and film processes become widespread in television, Barr suggests they are still used towards simulating live relay, describing intermediate film processes as producing a "delayed-action live transmission" and videotape as "a filmed record of a live programme." 39 Leaving aside the obvious counter-argument that television does show images of the past and future in its historical and fantasy programming, we can also dispute that cinema cannot 'diversify into present-tense or live images' using the history of cinema and television convergence. Theater Television, which has been absorbed into cinema and television practices, with its direct transmission of live events conceived of TV as a more purely live medium than broadcasting ever would.

\section{Industry}

For Caldwell, the convergence of film and television is contingent on an effacement of distinctions between the two media brought about by their absorption into multi-media conglomerates and concomitant dispersion across various electronic media platforms. ${ }^{40}$ It is not exactly convergence that Caldwell is talking about, since the scholar believes (or did in 2005) that the net result is to make cinema subject to television in the hierarchy of digital multi-media rather than flatten out their differences. Anderson saw convergence between the cinema and television industries as not simply a product of becoming the various limbs of large leisure conglomerates but characteristic of "the impulse to integrate movies and television." ${ }^{41}$ The use of the word 'impulse' suggests a natural state of convergence that is almost ahistorical and smacks of ontological pre-destiny. I wish to depart from this ontological determinism. Noel Carroll's work examining differences between television and film concludes that "none of the most commonly cited essential distinctions between film and TV hardly has... much to recommend them." ${ }^{42}$ Though Carroll pinpoints an ontological likeness of moving image material that could be compatible with convergence, he does not follow through on the historical uses of cinema and television nor does he give contextually plausible interpretations of how the potential of either media were and are exploited.

I have already demonstrated how convergent media formats such as the DVD were subject to a long history of marketing cinema to television audiences. It is also the case that industrial convergence of cinema and television significantly pre-dates the conglomerate. As recent historiographies of cinema and television convergence in Europe have demonstrated, funding for national cinema has often come from television companies, such as state broadcaster RAl's support for Italian film. ${ }^{43}$ In fact, Mazdon posits that without support from television institutions, the concept of national cinema cultures in countries such as Britain and France would be threatened. Attempts by movie studios during the formative period of television broadcasting to "get in on the ground floor" of the medium, ${ }^{44}$ such as Pay and Theater Television, contextualise later integrations of television and cinema inside a multi-media entertainment company. Industrial convergence of cinema and television in 1940s America was only prevented by the Federal Communications Commission refusing licences to the 'Big Five' movie studios in the wake of anti-trust suits designed to break studio dominance over movie theatres. It only took major studios until the mid-1950s to colonise US television production and start to exploit television as a platform for exhibiting their output.

There has been significant inter-emigration of screen artists, both in front of and behind the camera, across television and cinema throughout their common history. Discussion of this intermedial flow of personnel has reinforced the cultural and artistic validity of cinema. Caldwell has written about "auteur imports" in US television in the 1980s; American

38 Ibid, p. 53.

39 lbid, p. 55, 63.

40 John Thornton Caldwell, 'Welcome to the Viral Future of Cinema (Television)', Cinema Journal 45, 1 2005, p. 92: http://www.tft.ucla.edu/wpcontent/uploads/2012/02/2005-Welcome-to-the-Viral-Future-of-Cinema-CINEMA-JOURNAL.pdf

41 Christopher Anderson, Hollywood TV: The Studio System in the Fifties, University of Texas Press, 1994, p. 292.

42 Noel Carroll, Engaging the Moving Image, Yale University Press, 2003, p. 280.

43 Dorota Otrowska and Graham Roberts, eds, European Cinemas in The Television Age, Edinburgh University Press, 2007.

44 Tino Balio, ed, Hollywood in The Age of Television, Unwin Hyman, 1990, p. 20. 
cinema writers, directors and producers whose emigration to television he claims is responsible for contemporary American TV's aesthetic sophistication. ${ }^{45}$ Art cinema director David Lynch's appropriation of surrealism and the avantgarde in TV series Twin Peaks (1990-1991) would be a telling example here. Conversely, it is possible to see the television work of cinematic artists as a cultivation of authorship, as with director Lars von Trier's TV series Riget (19941997) which helped to forge body horror aspects of his later cinematic canon. Recent historical case studies of television and cinema artistry across Europe, including Germany and Spain, have observed a multi-directional flow of filmmakers "back and forth from television to cinema" without cultural or artistic loss. ${ }^{46}$ For example, director Roberto Rossellini made historical documentaries and mini-series for Italian television throughout the 1960s and 1970s, exploiting the potential for broadcasting as an "educational device."

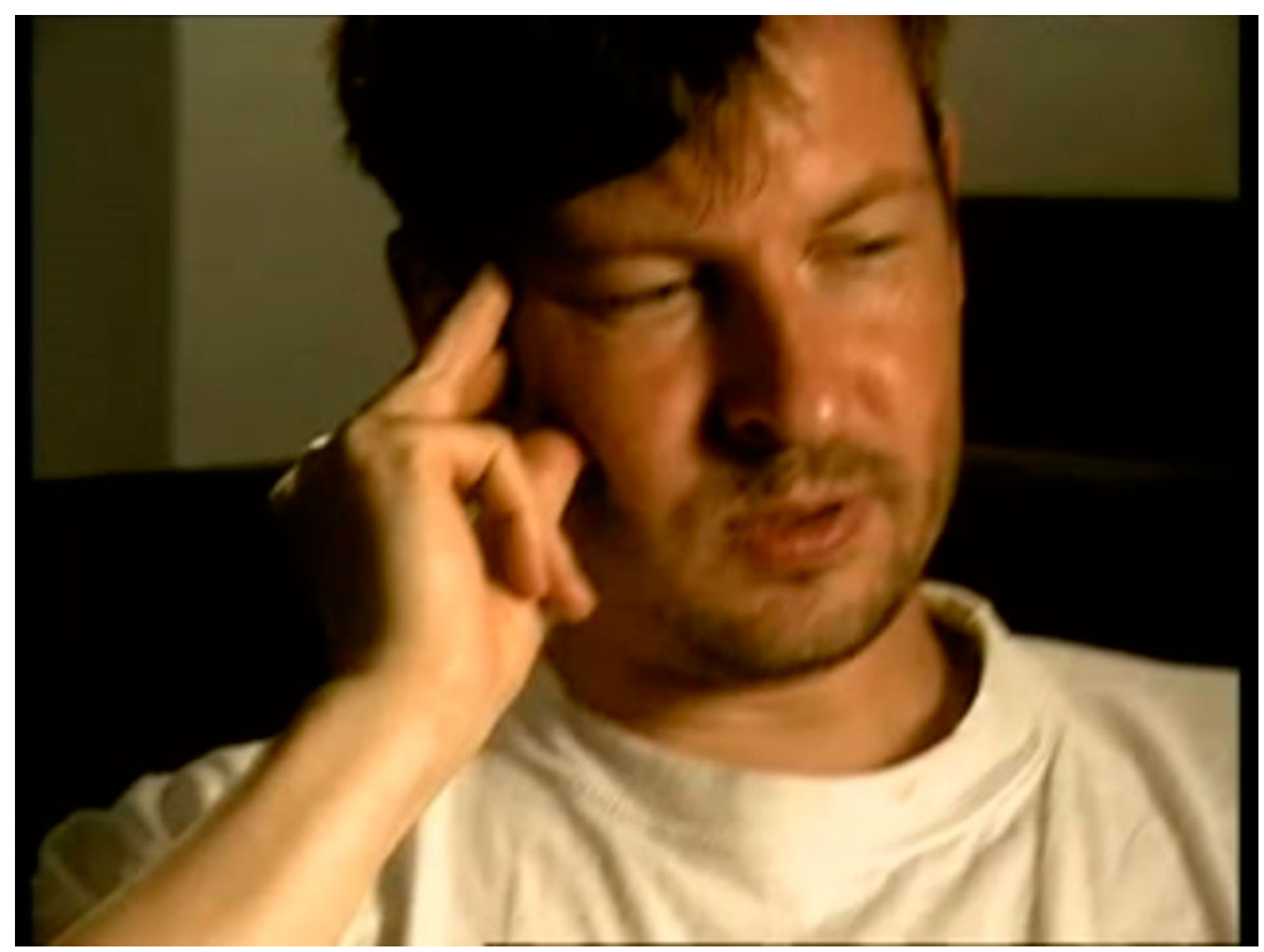

Video 4. The making of The Kingdom II. Click here to watch it

We can see how television artists bring legitimacy to cinema in certain historical contexts. In Britain, television and cinema director Ken Loach built the cultural status and social value of his cinematic canon, including Palme D'Or winner The Wind that Shakes the Barley (2006), on critical discourses of his synonymy with the 'Golden Age' of British television drama and concomitant political and aesthetic breakthroughs of his direction of dramas in the BBC Wednesday Play strand, such as Cathy Come Home (1966). Critical associations between television drama and theatre

45 John Thornton Caldwell, 'Welcome to the Viral Future of Cinema (Television)', Cinema Journal 45, 1 2005, p. 91: http://www.tft.ucla.edu/wpcontent/uploads/2012/02/2005-Welcome-to-the-Viral-Future-of-Cinema-CINEMA-JOURNAL.pdf

46 Dorota Otrowska and Graham Roberts, eds, European Cinemas in The Television Age, Edinburgh University Press, 2007, p. 3.

47 Hugo Salas, 'Great Directors: Roberto Rossellini', Senses of Cinema 21, July 2002, http://sensesofcinema.com/2002/great-directors/rossellini/ 
Tom James Longley Steward, Wide-Screen Television and Home Movies

in the British context meant that television artists such as Loach and writer-director Mike Leigh carried cultural cachet to the cinema. This further suggests that film and television convergence has often been an issue of transferred cultural value. While the fluid movement of screen artists between television and cinema in contemporary media is obviously a result of multi-media conglomerates and plural-platform digital media keeping the transition in-house, there were prior economic conditions that permitted this kind of artist inter-play. Cinematic artists from the classical period of Hollywood moved into early US television because of opportunities it provided for independent production. Alfred Hitchcock created the production company Shamley to produce anthology series Alfred Hitchcock Presents (1955-1962).

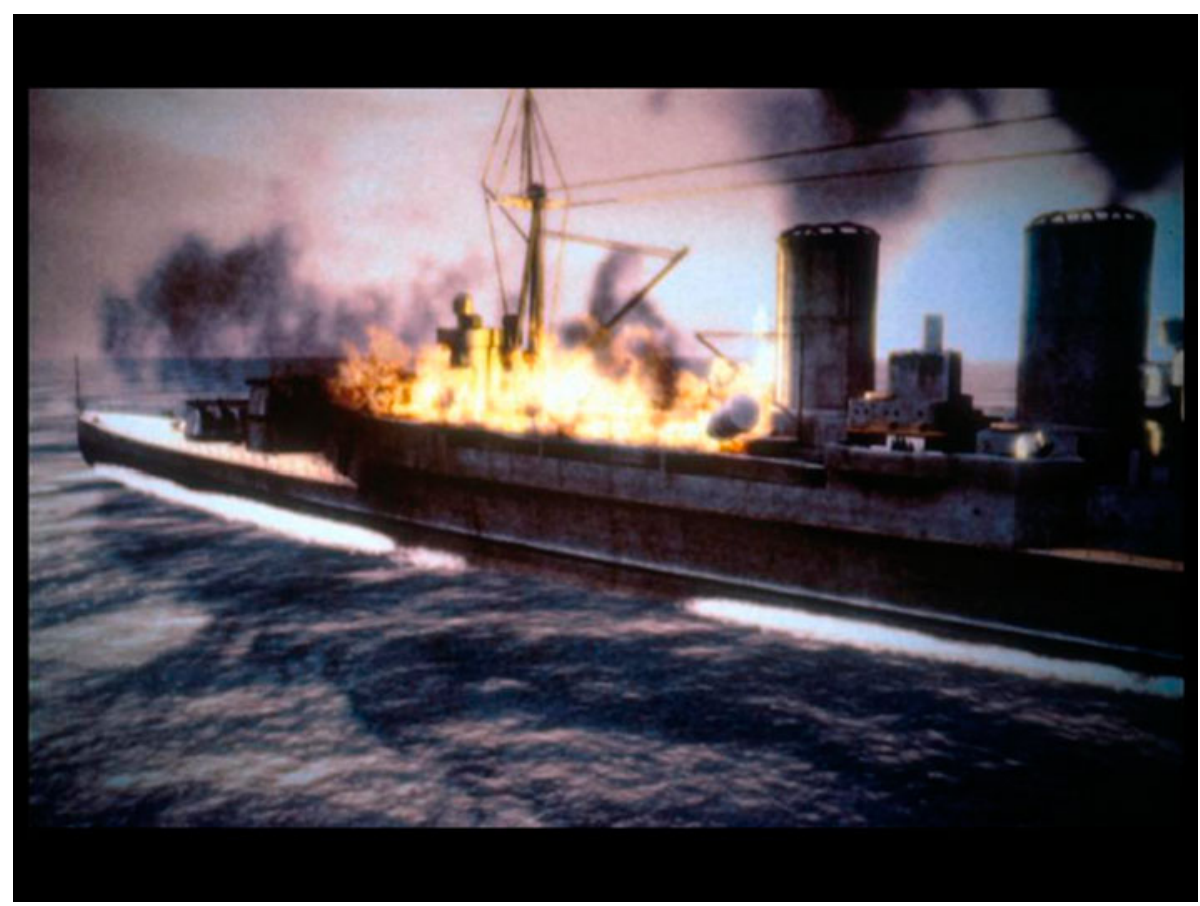

Video 5. Roberto Rossellini during an interview on television. Click here to watch it

\section{Conclusion}

The forms of television and cinema that are subject to convergence in the age of conglomerated digital media are already results of prior convergences between the two media active since the origins of television. They have shaped each other, especially in exhibition, form and industry. Television and cinema do not converge organically because they are both moving image media, but interrelate contingently because of their industrial, economic, cultural and artistic proximity and intersection at several key moments in their histories. The "contexts of appropriation" ${ }^{\prime 8}$ of each media favoured their convergence rather than an assumed ontological similarity. It is not a matter of one medium culturally colonising the other because of greater worth and sophistication as a form of art. The cultural status of television and cinema are relative and fluid across the boundaries of each media and straddle distinctions of low and high culture. However, cultural value has often been the impetus behind convergence. While there is much to learn here about the converged history of television and cinema, there is still more that this history can tell us about convergence.

Convergence is evident here not just in integrated multi-media form but also in new definitions of medium-specificity relative to another media. 
Beyond the importance of providing a more complex account of media history, there is a broader question at stake in this article about the convergence of moving image media. Is the archaeology of film and television convergence representative of a common ontology? Carroll would argue that possibilities for convergence erase any "period-specific" distinctions ${ }^{49}$ while Marriott maintains that the historical uses to which media are put determine them. ${ }^{50}$ Rather than pitting the scholars' definitions of medium-specificity against each other, we can reconcile what they are separately saying. At certain points in their shared history, both cinema and television have functioned as an integrated moving image media, while at other times they have not. While not ontologically identical, there is scope in the recurrent historical encounters between film and television to talk conceptually of a continuity of interaction between cinema and television. However, scholars wishing to pursue an archaeology of film and television convergence should continue to resist ontological pre-dispositions. The methodology of this article is also relevant to wider issues of convergence and new media. Though this article has specifically addressed film and television convergence, my approach can be adapted to historically qualify phenomenological discourses of digitally technologically determinist convergence in other media.

\section{Biography}

Tom Steward is an independent scholar currently based in San Diego, California. He previously taught Film and Television Studies, Media Studies, Cultural Studies and History at UK universities including The University of Warwick and Bournemouth University. He recently co-authored an article for The Journal of British Film and Television on the BBC TV drama Ghostwatch. He has also written about the authorship and production cultures of British and American television, television adaptations of Sherlock Holmes stories, and education in the BBC TV series Doctor Who. Tom is the author of the television blog Watching TV with Americans.

49 Noel Carroll, Engaging the Moving Image, Yale University Press, 2003, p. 278.

50 Stephanie Marriott, Live Television: Time, Space and the Broadcast Event, Sage, 2007, p. 13. 